patients in such evaluations were overlooked. Evaluation should not be considered as anything but constructive for those evaluated. It should provide feedback to improve patient care. Those involved in an evaluation with simulated patients should agree to the valuation. In addition, they must be instrumental in the design of the evaluation, especially the observations to be made by the simulator. Of course, the simulated patient does not have to be personally involved in the evaluation.

Since the simulated patient offers a standardized, unvarying medical problem, subsequent analysis of health needs produced by those who cared for the simulated patient can be carried out. However, if the simulated patient is to be involved in observation it is imperative that he be trained for consistency and objectivity. The anonymity of the simulation assures that no special treatment is given to this patient either consciously or unconsciously, as he is no reoognized as being different from the real patients in the system. The statement that simulated patients would be a drain on health care costs seems exaggerated. The cost of the odd non-patient should be well overbalanced by the value of the exercise in improved efficiency and effectiveness in real patient care. Quality control, to be effective, has a calculated cost. Though your article mentions other methods for evaluating health care, none is as direct as measuring the effect of health care delivery on patients by putting a standardized patien into the system. Many factors important to patient care cannot be detected by visits or by interviews of patients who are dependent on the health care system in which they are involved.

The great value of feedback provided by simulated patients to students, physicians, and nurses over the 12 years that I have utilized the technique has been amply demonstrated. In addition, the persons evaluated almost always appreciate the value of the information and insist on more evaluations of themselves by this technique. -I am, etc.,

H. S. BARROWS

McMaster University,

Hamilton, Ontario

\section{Drug Combinations for Anaesthesia}

SIR,-Dr. M. W. P. Hudson (9 November p. 345) advocates the use of intravenous methohexitone followed by diazepam (up to $10 \mathrm{mg}$ ) for induction of anaesthesia prior to endotracheal intubation. Since reading his letter I have tried this method in 25 inpatients (20 male, five female) soheduled for oral surgery. After intravenous injection of $80 \mathrm{mg}$ methohexitone and $10 \mathrm{mg}$ diazepam the patients were ventilated vigorously for one minute with nitrous oxide/oxygen and halothane $2 \%$ or, for very robust patients, $3 \%$. Conditions for intubation were considered to be difficult in 14 patients and impossible in four (requiring the use of suxamethonium). As part of a separate study arterial blood samples were taken for blood gas analysis as soon as stable anaesthesia was obtained. Surprisingly, anterial oxygen tensions $\left(\mathrm{PaO}_{2}\right)$ of less than $10.6 \mathrm{kPa}(80 \mathrm{~mm}$ $\mathrm{Hg}$ ) were found in five out of 17 patients, though clinically ventilation seemed to be adequate and the patients were breathing $35-40 \%$ oxygen.
To decide whether this effect was due to the drug combination 10 fit patients aged 30-42 years (nine male, one female) due for minor surgery had anaesthesia induced with 80-100 mg methohexitone and $10 \mathrm{mg}$ diazepam. The jaw was supported once the patient was asleep to avoid respiratory obstruction. Arterial blood samples were taken 2-3 min after induction while the patients were still breathing air and recovering from the transient apnoea which is a feature of this form of induction. Several were light enough to react to the needle prick. Arterial $\mathrm{Po}_{2}$ in these patients varied between $4 \cdot 12$ and $8.65 \mathrm{kPa}$ (31 and $65 \mathrm{~mm} \mathrm{Hg}$ ). The mean value $( \pm$ S.D.) was $6.45 \pm 1.21 \mathrm{kPa}(48.5$ $\pm 9.1 \mathrm{~mm} \mathrm{Hg}$ ). Slight cyanosis was detected in only one of these patients. In a 65-yearold woman having a similar induction $\mathrm{PaO}_{2}$ was $4.79 \mathrm{kPa}$ (36 mm Hg). These figures suggest that transient marked hypoxia is the rule with this drug combination used in patients breathing ambient air and presumably that funther doses of methohexitone or any degree of respiratory obstruction (which may be so difficult to detect $^{1}$ ) will prolong the hypoxic period.

We can expect to read more reports of deaths during dentistry ( 9 November 1974, p. $352 ; 8$ February 1975 , p. 341 ) as long as this drug combination is used withou oxygen enrichment, the case for which was so forcibly advocated in your recent leading article (8 February, p. 293). Reading the reports of the inquests on the unfortunate victims, one cannot but help feeling that by the time the patient has collapsed or become cyanosed and the alarm has been raised gross hypoxia has probably been present for a considerable period of time and recovery is unlikely. - I am, etc.,

\section{J. P. ALEXANDER}

Belfast City Hospital,

Belfast

Wise, C. C., et al., British Medical fournal, 1969,

Skin Reactions to Beta-blockers

SIR,-Since our original report ( 9 November, p. 321) we have extended our observations to a total of 48 patients with cutaneous reactions to practolol. Thirty-two of these patients have subsequently been treated with alternative beta-blocking agents (26 with oxprenolol, four with propranolol, and two with both). Fourteen of these patients had previously been challenged orally with practolol and all had developed a rash as previously described-usually within 2-3 days. No patient developed skin lesions during periods of up to 30 months' treatment with the alternative beta-blocking agents. In eight patients the practolol-induced rash was still present when alternative treatmen was started and in all of them it cleared completely within a few weeks. We have also observed conversion from positive to negative serology for antinuclear antibody in three patients subsequently treated with oxprenolol.

Despite the report by Dr. B. St. C. Cumberbatch (30 November, p. 528) of a psoriasiform skin reaction associated with oxprenolol treatment our observations demonstrate a lack of cross-reactivity between practolol and other beta-blocking agents with respect to these side effects. On the present evidence the advice of the manufacturers $^{1}$ to treat practolol-sensitive patients with alternative beta-blocking agents appears well founded.-We are, etc.

R. H. FELIX

F. A. IVE

M. G. C. DAHI

University Department of Dermatology

Royal Victoria Infirmary, 1 Downie, C. C. Adverse reactions associated with
practolol (Eraldin and Eramid). Letter to
Medical Practitioners, I.C.I. Ltd., 9 October
1974.

SIR,-It has been reported that practolol may induce acute generalized psoriasiform skin lesions $\mathrm{s}^{\mathrm{l}-3}$ and a recent report of an apparent acute exacerbation of psoriasis occurring in a patient taking oxprenolol suggests that other beta-blockers may share this side effect. As far as we are aware ${ }^{3}$ propranolol has not been so incriminated and thus the following case is of interest.

The patient, a 63-year-old woman with mild hypertension and renal impairment, was started on oral propranolol $40 \mathrm{mg}$ twice daily in May 1973. In the previous six years since her hypertension had first been noted by her general practitione she had received various antihypertensive regimens, none of which had included a beta-blocker. There was no past history of skin disorder. In May 1974 without change in her propranolol dosage, she developed an exfoliative psoriasiform eruption involving the trunk, scalp, limbs, and hands, and necessitating admission to hospital. Treatmen with local coal tar preparations produced marked erythema and subsequently petroleum jelly only was used. Skin biopsy was performed and the histological picture was not that of psoriasis. Sections showed hyperkeratosis overlying poriasis. Sections showed hyperkeratosis overlying a focally atrophic epidermis with evidence of epidermotropism in places. The dermis showed marked elastosis and free melanin pigment was scattered throughout the papillary dermis. A moderate but pleomorphic inflitrate was noted in the dermis and was predominantly perivascular in distribution. In general the appearances were considered compatible with a lichenoid drug eruption. As the patient's blood pressure appeared to have settled propranolol was discontinued in June 1974 and has never been restarted. Her skin lesions were slow to clear, but by January 1975 no trace of any abnormality remained. During this period, however, there was a severe deterioration in her rena function which has proved to be irreversible.

While it is impossible to be sure that this condition was induced by propranolol, the oocurrence of such lesions in a woman of this age is unusual and the temporal relationship of the psoriasiform eruption to the administration of propranolol was similar to that seen with practolol. ${ }^{2}$ Propranolol is now a commonly used drug and this complication must be rare, though it is conceivable that such cases may be missed in view of the long interval between commencement of the drug and the onset of symptoms.-We are, etc.,

Paul L. Padfield

D. G. BEEVERS

M.R.C. Blood Pressure Unit,

Rebecca COCHRAN A. MCQUEEN

University Department of Dermatology,

Western Infirmary,

1 Ridley, C. M., British Medical fournal, 1974, 4 Felix, 719. H., Ive, F. A., and Dahl, M. G. C. British Medical fournal, 1974, 4, 321.
Department of Health and Social Security, Department of Health and Social Security,
Committee on Safety of Medicines, Adverse Re-
action Series No. 11. London, D.S.S. 1975.

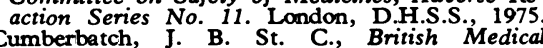
fournal, 1974, 4 , 528 . 